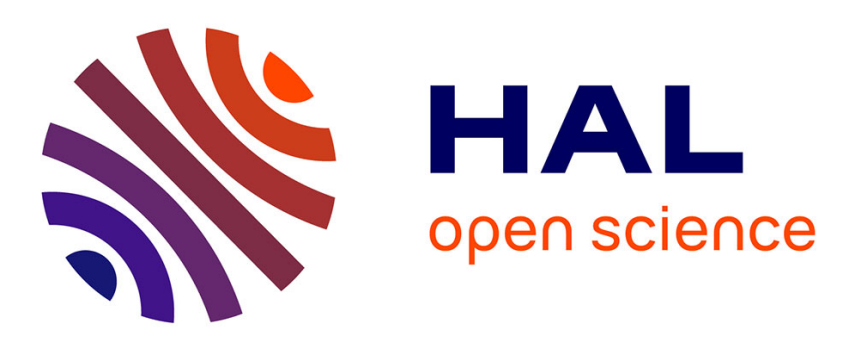

\title{
Not merely noxious? Time-dependent hormesis and differential toxic effects systematically induced by rare earth elements in Escherichia coli
}

Didier Techer, Nicolas Grosjean, Bénédicte Sohm, Damien Blaudez, Marie Le Jean

\section{To cite this version:}

Didier Techer, Nicolas Grosjean, Bénédicte Sohm, Damien Blaudez, Marie Le Jean. Not merely noxious? Time-dependent hormesis and differential toxic effects systematically induced by rare earth elements in Escherichia coli. Environmental Science and Pollution Research, 2020, 27 (5), pp.56405649. 10.1007/s11356-019-07002-z . hal-02523496

\section{HAL Id: hal-02523496 \\ https://hal.science/hal-02523496}

Submitted on 7 Apr 2020

HAL is a multi-disciplinary open access archive for the deposit and dissemination of scientific research documents, whether they are published or not. The documents may come from teaching and research institutions in France or abroad, or from public or private research centers.
L'archive ouverte pluridisciplinaire HAL, est destinée au dépôt et à la diffusion de documents scientifiques de niveau recherche, publiés ou non, émanant des établissements d'enseignement et de recherche français ou étrangers, des laboratoires publics ou privés. 


\title{
Not merely noxious? Time-dependent hormesis and differential toxic effects systematically induced by rare earth elements in Escherichia coli
}

\author{
Didier Técher ${ }^{1,2} \&$ Nicolas Grosjean ${ }^{1,3} \&$ Bénédicte Sohm ${ }^{1} \&$ Damien Blaudez $^{3} \&$ Marie Le Jean ${ }^{1}$ \\ ${ }^{1}$ CNRS, LIEC, Université de Lorraine, Metz, France \\ ${ }^{2}$ Cerema, Laboratoire de Nancy, Nancy, France \\ ${ }^{3}$ CNRS, LIEC, Université de Lorraine, Nancy, France
}

\begin{abstract}
Progressive rare earth element (REE) enrichment in aquatic environments worldwide and their resulting anthropogenic anomalies have highlighted the need for a better understanding of their biological effects, with a special emphasis on microbial cells since they play a crucial role in good ecosystem functioning. Therefore, the primary aim of this work was to achieve simultaneous characterization of the 16 REE toxicity effects on the growth kinetics of the commonly found Gram-negative bacterium E. coli (BW25113 strain). Bacterial growth curve modelling showed hormetic effects in the presence of REEs, while EC50 determination (in the mid-log phase) indicated that the four HREEs from Er to Lu in addition to $\mathrm{Y}$ were the most toxic metals (EC50 in the range of 8.3 to $3 \mu \mathrm{M}$ ), just after Sc (ECso of $1.1 \mu \mathrm{M})$. Additional subcellular parameter assessment revealed cell membrane lipid peroxidation as well as enhanced membrane depolarization and permeability in the presence of $\mathrm{La}$, $\mathrm{Gd}$, or $\mathrm{Yb}$ as representatives of LREEs and HREEs. These subcellular effects appeared to be more intense with $\mathrm{Gd}$ and $\mathrm{Yb}$ compared with La-exposed cells, in relation to the overall higher toxicity potential reported for HREEs on bacterial growth. Also, the cellular ATP production decreased after REE exposure at their EC50. Finally, these results emphasize the importance of growth kinetic consideration as well as the complexity of REE biological effect mechanisms towards bacteria.
\end{abstract}

Keywords: Rare earth elements; Lanthanides; Hormesis; Escherichia coli; Cytotoxicity

\section{Introduction}

Rare earth elements (REEs) encompass the group of the 15 lanthanides (lanthanum (La), $Z=57$, to lutetium (Lu), $\mathrm{Z}=71)$ in addition to scandium ( $\mathrm{Sc}, \mathrm{Z}=21$ ) and $\mathrm{yttrium}(\mathrm{Y}, \mathrm{Z}=39$ ), as stated by the International Union of Pure and Applied Chemistry (Connely et al. 2005). According to the literature, a distinction is usually made between low atomic number REEs, i.e. "light" REEs (LREEs, from lanthanumto europium in addition to scandium), and high atomic number REEs, i.e. "heavy" REEs (HREEs, from gadolinium (Gd) to lutetium in addition to yttrium) (Beaudry and Gschneidner 1978). REEs present similar chemical properties due to their analogous electronic configurations. Indeed, their valence is located in the inner $4 \mathrm{f}$ subshell orbital for the lanthanides $\mathrm{Ce}$ to $\mathrm{Lu}$, whereas for Sc, Y, and $\mathrm{La}$, the outer three electrons are $(3 \mathrm{~d} 4 \mathrm{~s})_{3},(4 \mathrm{~d} 5 \mathrm{~s})_{3}$, and $(5 \mathrm{~d} 6 \mathrm{~s})_{3}$, respectively (Beaudry and Gschneidner 1978). Moreover, a reduction in the lanthanide ionic radii is observed with increasing atomic number, corresponding to the "lanthanide contraction" (Beaudry and Gschneidner 1978). These atomic features make REEs especially suitable for the production of very light and efficient alloys or catalysts that can be used in all types of modern industries, including electronic engineering and green technologies such as solar panels and wind turbine manufacturing (Haque et al. 2014). In addition, some lanthanides such as La are commonly used as agricultural fertilizers, mainly in China (Pang et al. 2001). Other REEs are also used for medicinal purposes (Cotton and Harrowfield 2012, and references therein, Ghahramani et al. 2013), with one of the most known applications being the use of Gd as a contrasting agent for magnetic resonance imaging (Bellin and Van Der Molen 2008). As a consequence, the global demand and use of REEs has considerably risen during the last few decades (Haque et al. 2014; Nuss and Blengini 2018). Currently, REEs are considered "technology critical elements" (TCE), and efforts have been undertaken to better address the issues of sustainable resource management, with a special emphasis on their environmental fate and toxicity (González et al. 2014; Haque et al. 2014; Nuss and Blengini 2018). REEs are usually detected in the ng L-1 to a few $\mu \mathrm{g} \mathrm{L-1}$ range inmost freshwater bodies, with substantial variations up to 200 $\mu \mathrm{g} \mathrm{L}-1$ reported for rivers in Japan (Migaszewski and Gałuszka 2015; Uchida et al. 2006). They may form hardly soluble hydroxides (i.e. $\left.\mathrm{Ln}(\mathrm{OH})_{3}\right)$ at near neutral or alkaline $\mathrm{pH}$ or precipitate with common inorganic ligands (phosphates, carbonates, etc.) (Migaszewski and Gałuszka 2015), thus decreasing their bioavailability. Such phenomena often lead to an underestimation of their toxicity potential under environmental conditions (González et al. 2014). REE complexation and solubilization in the presence of inorganic ligands such as nitrate, sulfate, and chloride as well as organic ligands such as citrate and malate may occur, resulting in an enhanced availability and toxicity potential at the cellular level (Migaszewski and Gałuszka 2015; Sachs et al. 2015). In addition, recent studies reported substantial anthropogenic REE anomalies in several continental hydrosystems and estuarine sediments (Hissler et al. 2014). Wastewater treatment plants receiving different kinds of domestic, hospital, and industrial effluents are often considered the most prominent source of REE discharge into polluted rivers (Hissler et al. 2014).Within this context, anthropogenic anomalies raise the issue of REE-associated environmental risks. 
Bacteria are key microorganisms that play crucial roles in all biogeochemical cycles and are directly exposed to REEenriched water or soil solution. In addition, recent studies with farm animals (piglets or broiler chickens) showed that feeding trials with an REE-enriched diet may alter the predominant faecal microbiota in those REEtreated animals (Cai et al. 2015; Kraatz et al. 2006). REEs are expected to enter bacterial cells through a variety of passive and active uptake mechanisms, potentially leading to either positive or detrimental biological effects (Bayer and Bayer 1991; Migaszewski and Gałuszka 2015; Takahashi et al. 2010; Wakabayashi et al. 2016). As an illustration, anecdotal hormetic effects of REEs on bacterial growth and metabolism were reported byWenhua et al. (2003), whereas it has been well documented in the area of plant biology (Agathokleous et al. 2018). Whether hormesis is a common feature following bacterial exposure to the 16 REEs and to what extent common REEmediated toxicity patterns can be found following microbial exposure remains to be clarified. The aim of this work was to investigate the mode of action of REEs on bacteria using the model Gram-negative Escherichia coli BW25113. Although E. coli is a wellknown gut microbe, and has been extensively studied as such, it also established itself as a soil, water or even a plant microbe (Blount 2015 and references therein). Beside environmental pollution cases due to faeces originated E. coli, these bacteria have also adapted to non-host environment (Walk et al. 2009), becoming a member of natural microbial communities (Jang et al. 2017). The presence in the environment of E. coli accidentally disseminated or environmentally persistent and adapted, combined with themyriad tools related to this species make E. coli a model of choice to study the response of Gramnegative bacteria, to emerging pollutants such as REEs in aerobic conditions frequently encountered in soils or waterbodies. To better address the time-dependent toxicity of REEs, a comparative assessment of the impacts of light and heavy REEs on bacterial growth was first performed using in vitro microplate growth experiments. Then, the REEmediated biological effects were characterized at the cellular level through bioluminescent measurement for ATP cellular production monitoring and flow cytometry analyses relying on the use of specific fluorescent probes for lipid peroxidation determination (in relation to oxidative stress) and cell membrane depolarization along with membrane permeability.

\section{Materials and methods}

\section{REE water solution preparation}

All 16 REEs were obtained from Sigma-Aldrich Chemical Co. (St. Louis, MO, USA). Stock solutions (10 mM) of $\mathrm{LaCl}_{3}, \mathrm{La}_{2}\left(\mathrm{SO}_{4}\right)_{3}, \mathrm{CeCl}_{3}, \mathrm{PrCl}_{3}, \mathrm{NdCl}_{3}, \mathrm{SmCl}_{3}, \mathrm{EuCl}_{3}, \mathrm{ScCl}_{3}, \mathrm{TbCl}_{3}, \mathrm{DyCl}_{3}, \mathrm{HoCl}_{3}, \mathrm{ErCl}_{3}, \mathrm{TmCl}_{3}, \mathrm{LuCl}_{3}$, and $\mathrm{YCl}_{3}$ were prepared in Milli-Q water $(18.2 \mathrm{M} \Omega \mathrm{cm})$ that was filter-sterilized through a $0.22-\mu \mathrm{m}$ pore size filter (Millipore), and stored at $4{ }^{\circ} \mathrm{C}$ until use.

\section{Growth medium and bacterial inoculum preparation}

The model strain Escherichia coli BW25113 was obtained from GE Healthcare Europe GmbH (Orsay, France). A MOPS minimal medium (depleted of free phosphate ion) was used for all dose-response microplate experiments. This culture medium consisted of the following components: $\mathrm{NaCl}(80 \mathrm{mM}), \mathrm{KCl}(20 \mathrm{mM}), \mathrm{NH}_{4} \mathrm{Cl}(20 \mathrm{mM})$, $\mathrm{Na}_{2} \mathrm{SO}_{4}(3 \mathrm{mM}), \mathrm{MgCl}_{2}-6 \mathrm{H}_{2} \mathrm{O}(0.98 \mathrm{mM}), \mathrm{CaCl}_{2}-2 \mathrm{H}_{2} \mathrm{O}(0.2 \mathrm{mM})$, and MOPS (3-(N-morpholino)propanesulfonic acid) $\mathrm{C}_{7} \mathrm{H}_{15} \mathrm{NO}_{4} \mathrm{~S}, 99.5 \%$ purity) $(20 \mathrm{mM})$. It was supplemented with sodium 2- glycerophosphate $(10 \mathrm{mM})$ and $0.1 \%(\mathrm{v} / \mathrm{v})$ of a trace element solution SL7 (Biebl and Pfennig 1981) containing $\mathrm{ZnCl}_{2}(0.51 \mathrm{mM}), \mathrm{MnCl}_{2}-2 \mathrm{H}_{2} \mathrm{O}$ $(0.62 \mathrm{mM}), \mathrm{H}_{3} \mathrm{BO}_{3}(0.97 \mathrm{mM}), \mathrm{CoCl}_{2}-6 \mathrm{H}_{2} \mathrm{O}(0.84 \mathrm{mM}), \mathrm{CuCl}_{2}-2 \mathrm{H}_{2} \mathrm{O}(0.12 \mathrm{mM}), \mathrm{NiCl}_{2}-6 \mathrm{H}_{2} \mathrm{O}(0.067 \mathrm{mM})$, $\mathrm{Na}_{2} \mathrm{MoO}_{4}-2 \mathrm{H}_{2} \mathrm{O}(0.17 \mathrm{mM}), \mathrm{FeCl}_{3}-6 \mathrm{H}_{2} \mathrm{O}(5.5 \mathrm{mM})$, and $1 \mathrm{~mL}$ of $\mathrm{HCl}(25 \%)$. Glucose $(28 \mathrm{mM})$ was added as the carbon source. Bacteria were grown overnight on an orbital shaker $\left(180 \mathrm{rpm}, 37^{\circ} \mathrm{C}\right)$. Then, E. coli subcultures to renewed minimal medium were made until the optical density (OD600) reached approximately 0.4 to 0.6 (midexponential growth phase). After incubation, the cultures were subsequently harvested by centrifugation $(3800 \mathrm{~g}$, $10 \mathrm{~min}$ ), washed twice with sterileMilli-Q water and the pellet was resuspended in fresh mediumto an optical density of 0.15 for immediate use in dose-response experiments.

\section{Dose-response growth inhibition assays}

Dose-response inhibition of bacterial growth under REE exposure was studied using standard 96-well cell-culture microplates. For each REE, $10 \mu \mathrm{L}$ of an increasing concentration series was first distributed in the exposure wells in triplicate. The following concentrations (expressed as final concentration in $\mu \mathrm{M}$ ) were selected (based on preliminary doseinhibition range assays): $1,2,3,4,5,6,12,18,24,30$, and 40, including control wells (MOPS minimum medium only with $10 \mu \mathrm{L}$ Milli-Q water instead of REEs). Then, $190 \mu \mathrm{L}$ of the previously prepared bacterial suspension (in the MOPS minimal medium) was directly added to each well using a multichannel pipette (Eppendorf). The plates were incubated on a rotary shaker $\left(180 \mathrm{rpm}, 37^{\circ} \mathrm{C}\right)$, and the growth was monitored at an interval of approximately 20 to 30 min until stationary phase (about 7.5 h) using a Biochrom Asys Expert Plus microplate reader. 


\section{Bacterial exposure to REEs and subcellular parameter assessment}

To better understand the process of injury that bacterial cells could undergo during REE exposure, control, and REEexposed bacteria were analyzed through flow cytometry according to the protocol described by (Sohm et al. 2015) with slight modifications and ATP cellular production was also monitored. Briefly, subcultured E. coli cells were resuspended for $5 \mathrm{~h}$ in a MOPS buffer containing appropriate dilutions of $\mathrm{LaCl}_{3}, \mathrm{GdCl}_{3}$, or $\mathrm{YbCl}_{3}$ to their corresponding $\mathrm{EC}_{50}$ (determined in the middle exponential phase). For flow cytometry analysis, cell suspensions from each REE treatment (plus a control group) were stained using one of the four following fluorescent probes: Syto 9 (BacLight kit, Invitrogen, CA, USA) for total cell count, 4,4-difluoro-3a, 4a-diaza-sindacene (BODIPY$\mathrm{C} 4$; B3824,Molecular Probes) for the detection of lipid peroxidation (in relation to reactive oxygen species (ROS) formation), bis-(1,3-dibutylbarbituric acid) trimethine oxonol ( $\mathrm{DiBAC}_{4}(3)$; Sigma-Aldrich, Germany) for membrane potential loss, and propidium iodide (PI, BacLight kit, Invitrogen) for membrane integrity assessment. Appropriate bacterial sample dilutions were incubated in the dark at ambient temperature for 10 min with each probe separately. The final concentrations of Syto 9, BODIPY-C4, $\mathrm{DiBAC}_{4}(3)$, and PI were fixed at 5, 2.5, 10, and $30 \mu \mathrm{M}$, respectively. All samples were analyzed on a BD AccuriTM ${ }^{\mathrm{T}} 6$ flow cytometer (BD Biosciences, NJ, USA) with a $488 \mathrm{~nm}$ laser for dye excitation. Syto9, BODIPY-C4, and DiBAC4(3) fluorescence signals were collected using a 533-30-nm bandpass filter (FL1 channel), whereas PI was recorded on the FL3 channel with a 675-25$\mathrm{nm}$ bandpass filter. For each sample, at least 10,000 events were recorded. Data acquisition and analyses (triplicate experiments) were achieved using BD CSAMPLER ${ }^{\mathrm{TM}}$ software (BD Biosciences, NJ, USA). For cellular ATP production measurement, cells concentration was recorded by optical density (OD600) and ATP concentration was determined on $25 \mu \mathrm{L}$ of cell suspension using ATP bioluminescent Assay kit HS II (Sigma-Aldrich, Germany) following the manufacturers recommendations. Bioluminescence was recorded on a SAFAS luminometer (SAFAS, Monaco). ATP cellular concentration was normalized according to cells number.

\section{REE analysis}

Nominal concentrations of $\mathrm{LaCl}_{3}, \mathrm{GdCl}_{3}$, and $\mathrm{YbCl}_{3}$ at $2 \mu \mathrm{M}$ each and at their respective $\mathrm{EC}_{50}$ were compared with measured concentrations in the minimal growth medium (for E. coli growth microplate assays) and MOPS buffer (for subcellular parameter analyses) (Table 1). REE-containing growth medium and MOPS buffer were diluted 100 times with Milli-Q water and filtered through a $0.22-\mu \mathrm{m}$ pore size filter prior to acidification in $2 \% \mathrm{HNO}$ (69\%, AppliChem Panreac). Concentrations were determined in triplicate using inductively coupled plasma mass spectrometry (ICP-MS, X Series II Model, Thermo Fischer Scientific, Courtaboeuf, France). The validity of the analytical method was checked by means of standard reference material (Surface Water - Trace metals, SPS-W1, LGC Prochem standards). Since only slight differences could be observed between nominal and measured REE concentrations in both media (Table 1), throughout the present study, nominal concentrations were used for growth curve modelling and subsequent $\mathrm{EC}_{50}$ determination.

\begin{tabular}{|c|c|c|}
\hline $\begin{array}{c}\text { Rare Earth Element - } \\
\text { Exposure medium }\end{array}$ & $\begin{array}{c}\text { Nominal concentration } \\
(\boldsymbol{\mu M})\end{array}$ & $\begin{array}{c}\text { Measured concentration } \\
(\boldsymbol{\mu M})\end{array}$ \\
\hline $\begin{array}{c}\text { La - Minimal growth } \\
\text { medium }\end{array}$ & 2 & $1.92+/-0.02$ \\
\hline $\begin{array}{c}\text { La - Minimal growth } \\
\text { medium }\end{array}$ & 18.2 & $20.33+/-0.53$ \\
\hline $\mathbf{L a}-$ MOPS medium & 18.2 & $20.3+/-0.05$ \\
\hline $\mathbf{Y b}-\begin{array}{c}\text { Minimal growth } \\
\text { medium }\end{array}$ & 2 & $2.06+/-0.01$ \\
\hline $\mathbf{Y b}-$ Minimal growth \\
medium & 4 & $4.06+/-0.03$ \\
\hline $\mathbf{Y b}-$ MOPS medium & 4 & $4.15+/-0.04$ \\
\hline
\end{tabular}

Table 1. Nominal and measured concentrations $(\mu \mathrm{M})$ of $\mathrm{La}$ and $\mathrm{Yb}$ in minimal growth medium (containing glucose) and MOPS medium (for flow cytometry analyses) corresponding to the time at $t_{0}$ just after bacterial inoculum introduction into the respective media. Data are expressed as the mean $+/-\operatorname{SD}(n=3)$.

\section{Statistical analyses}

All data were expressed as the mean $\pm \mathrm{SD}$ of at least triplicate samples. The differences between groups were determined by ANOVA followed by Holm-Sidak post hoc test $(\mathrm{p}<0.05)$. Pairwise comparisons of dose groups against the control were made with standard t tests. Bacterial growth at each time point was expressed as a percentage of the control, which was calculated by dividing theOD 600 of the REE-exposed groups with that of the control groups. The dose-response curves obtained for each REE at time points of $3.3 \mathrm{~h}$ and $7.3 \mathrm{~h}$ of incubation 
(corresponding to the mid-exponential growth and stationary phase of the control groups, respectively) were fitted by a series of loglogistic models of two-, three-, four-, and five-parameters which are general fitting functions for non-linear dose-response data analysis (Ritz and Streibig 2005). The Cedergreen-Ritz-Streibig (four-parameter) model was also included to specifically describe dose-response curves showing hormesis at low doses (Ritz and Streibig 2005). Subsequently, comparison of the different models according toAkaike's information criterion (AIC) allowed for the best model choice prior to EC50 calculation. EC50 corresponded to the effective REE concentration that inhibits $50 \%$ of the bacterial OD600. The data analyses were performed with the add-on package for dose-response curves "drc" (Ritz and Streibig 2005) for R version 3.4.4. (R Core Team 2013).

\section{Results and discussion}

\section{Bacterial growth and toxicity assessment}

The E. coli growth curves during exposure to REEs are reported in Fig. 1a, c, and e and Fig. S1 and S2.

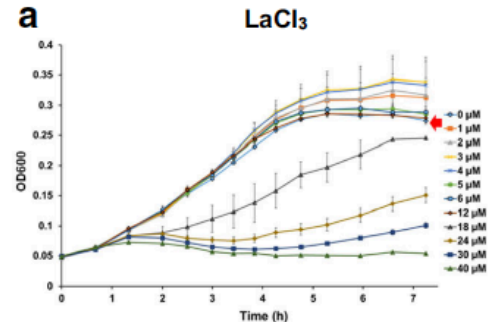

b

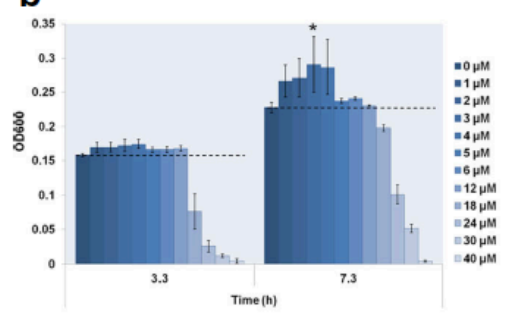

C

C

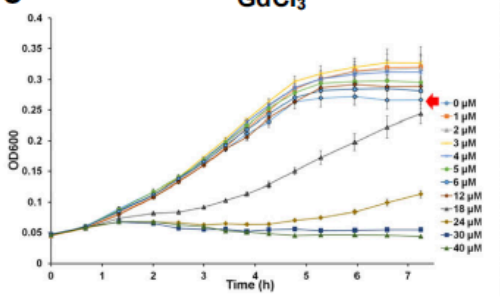

d

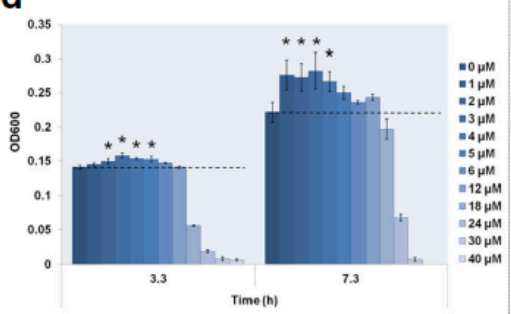

e $\quad \mathrm{YbCl}_{3}$

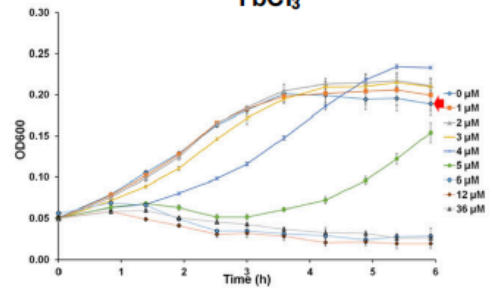

f

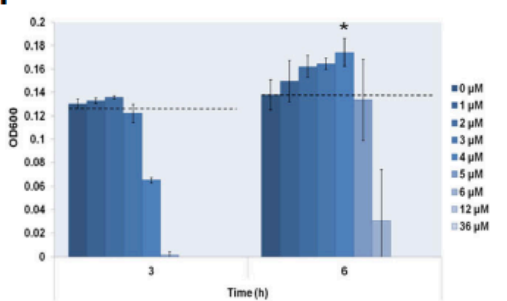

Figure 1. Growth curves of $E$. coli and the corresponding $\mathrm{OD}_{600}$ (determined in the mid-log and stationary phase) during incubation with $\mathrm{LaCl}_{3}(\mathrm{~A}, \mathrm{~B}), \mathrm{GdCl}_{3}(\mathrm{C}, \mathrm{D})$ and $\mathrm{YbCl}_{\mathbf{3}}(\mathrm{E}, \mathrm{F})$; control group growth curve is indicated by a red arrow. Data are expressed as the mean $+/-\operatorname{SD}(n=3)$. * indicates a significant difference from the control group $(p<0.05)$.

For all the tested metals, the highest concentrations lead to noticeable growth inhibition, indicating that all REEs were toxic to bacteria in our experimental conditions. This concentration-dependent inhibition of bacterial growth allowed the determination of $\mathrm{EC}_{50}$ using general (asymmetric) log-logistic models at middle exponential phase (EC50_A) and at late stationary phase (EC50_B), respectively (Figs. 2 and 3). Thus, the 16 REEs could be ranked from the least toxic, i.e. La either in the chloride (EC50_A of $18.1 \mu \mathrm{M}$; Table 2) or sulfate form (EC50_A of 24.6 $\mu \mathrm{M}$; Table 2), to the most potent, i.e. Sc with an EC50_A of $1.1 \mu \mathrm{M}$ (Table 2). Overall, a global pattern of HREEs being more toxic than LREEs could be described, with few exceptions among "HREEs" (e.g. Gd was more toxic than $\mathrm{Tb}$, Dy, or Ho; Table 2) and Sc, which is considered a "LREE" (Table 2).

Similar observations were reported by Weltje et al. (2004) using a medium depleted of phosphate (i.e. $3.02 \% \mathrm{NaNO}_{3}$ in the medium) for the assessment of Aliivibrio fischeri bioluminescence under REE exposure. In the present work, sodium 2-glycerophosphate was used instead of phosphate salts in the growth medium formulation to prevent REE precipitation and to provide a satisfactory alternative phosphorus source (Lemke et al. 1995). Its use has been reported in several studies of bacterial response to $\mathrm{Cu}$ (Outten et al. 2001), $\mathrm{Pb}$ (Borremans et al. 2001), and Zn (Jackson et al. 2008). Also, the MOPS minimum culture medium was selected because of its harmlessness (Neidhardt et al. 1974) and its previous use in metal effects studies on bacteria (Mergeay et al. 1985; Borremans et al. 2001). The estimation of the REE chemical forms in this medium using the software Visual MINTEQ ver.3.1 revealed that they remained ionic (data not shown) therefore suggesting a high bioavailability. In fact, it seems that in the absence of ligands inducing REE precipitation, such as free phosphate ions, a strong increase in toxicity is usually observed along with increasing atomic numbers (Weltje et al. 2004). As an illustration, Weltje et al. (2004) showed that Lu3+(the heaviest HREE) was more toxic than La3+(the lightest 
LREE), and practically of equal toxicity as $\mathrm{Cu}_{2}+$ with an $\mathrm{EC}_{50}=1.4 \mu \mathrm{M}(\sim 269 \mu \mathrm{g} \mathrm{L}-1)$, the toxicity depended mainly on the free $\mathrm{Lu}_{3}+$ concentrations.
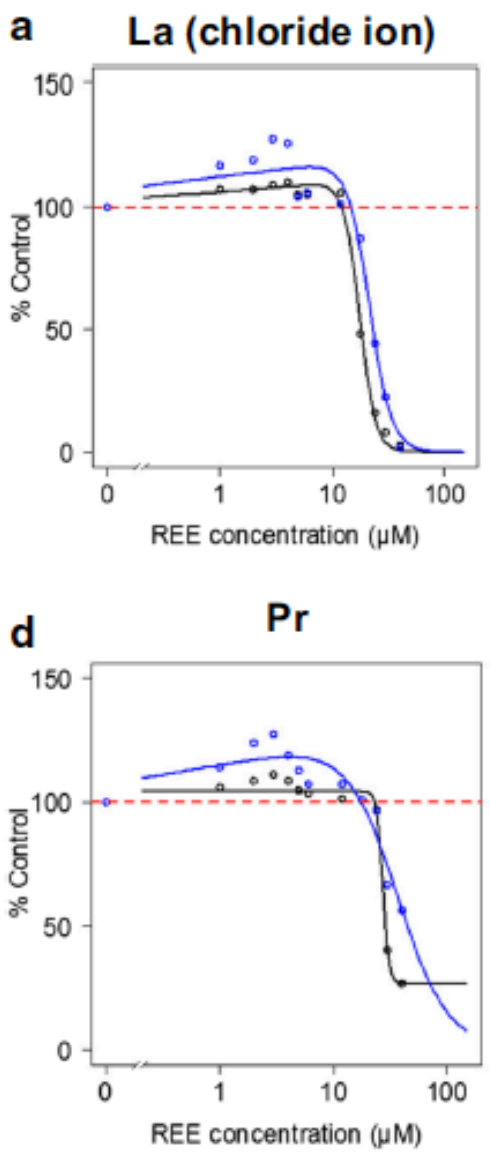

g

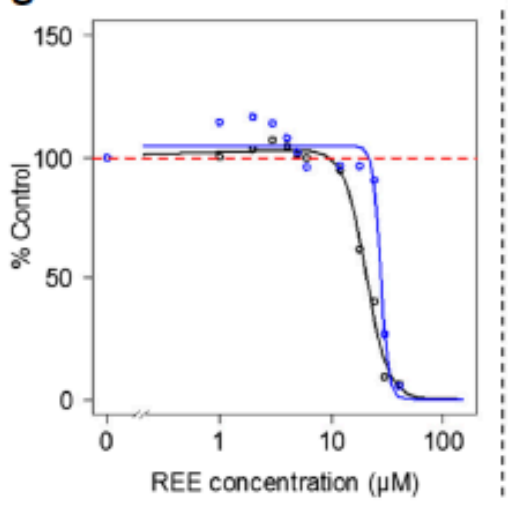

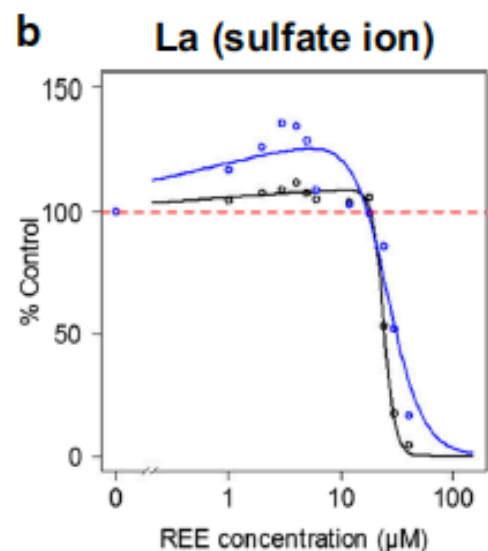
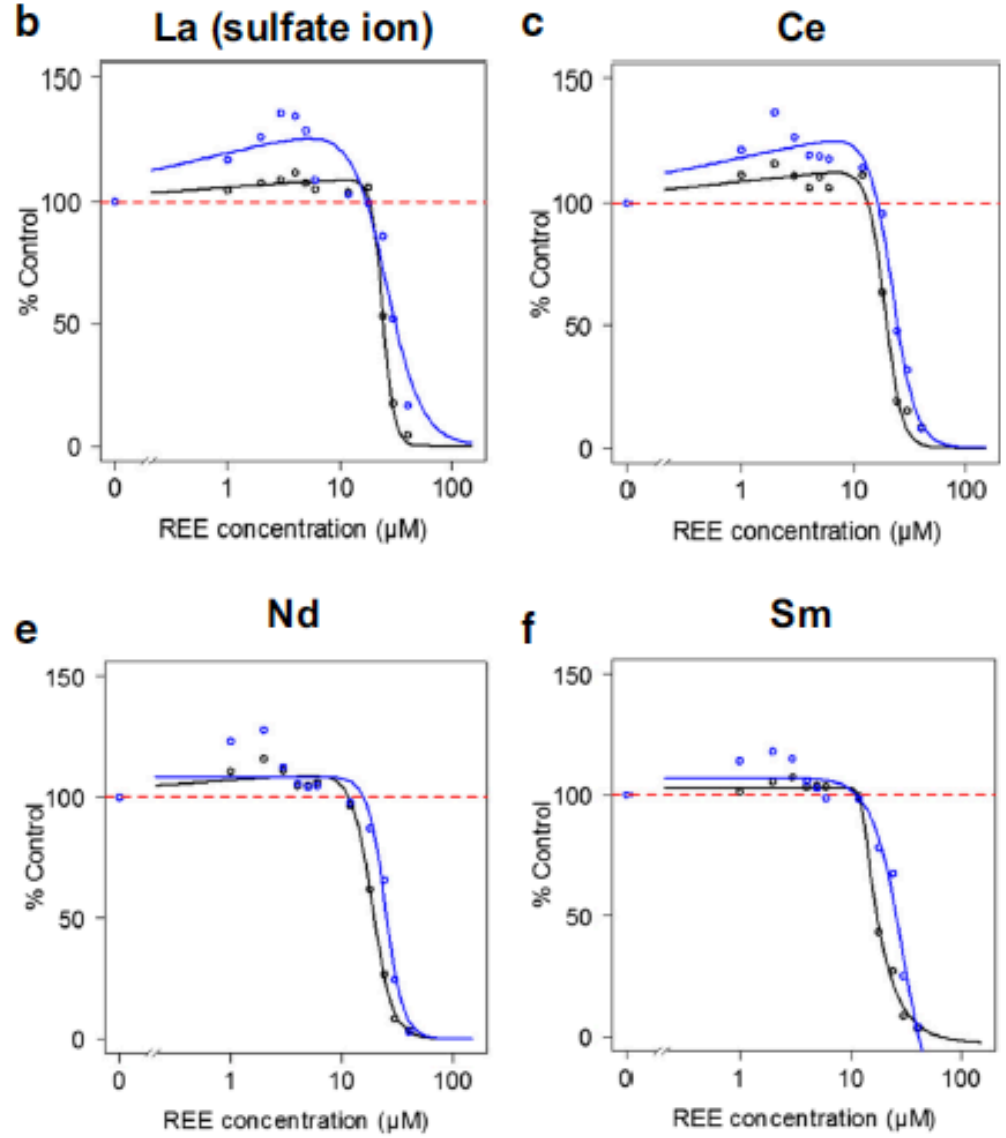

h

\section{Sc}

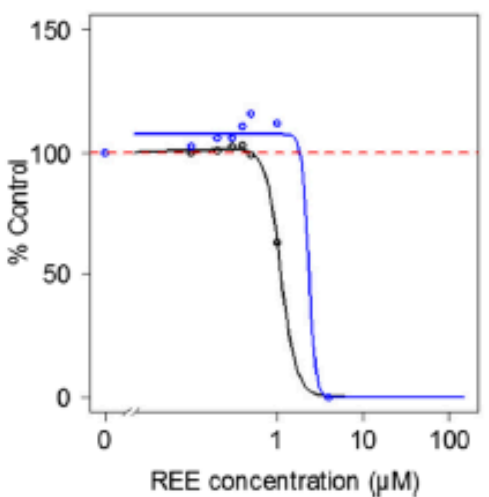

Figure 2. Dose-response curves following $E$. coli exposure to LREEs at mid-log phase (black line) and stationary phase (blue line). Data are expressed as the percentage of the control group (based on $\mathrm{OD}_{600}$ measurements), with the dashed red line representing $100 \%$ of the control.

More recently, González et al. (2015) also determined a lower EC50 nominal value (with standard A. fischeri toxicity testing medium) for $\mathrm{Lu}$ compared with $\mathrm{Gd}$ and Ce, i.e. $3200 \mu \mathrm{g} \mathrm{L}-1$ and $>6400 \mu \mathrm{g} \mathrm{L}-1$, respectively, for bioluminescence inhibition. Using a slightlymodified A. fischeri medium $(2 \% \mathrm{NaCl})$, Kurvet et al. (2017) also reported the same trends regarding increased toxicity with the heaviest REEs. Interestingly, the higher toxicity of HREEs over LREEs previously measured with selected REEs using A. fischeri bioluminescence assays (González et al. 2015; Kurvet et al. 2017) is consistent to our findings that extend this tendency to the whole set of the 16 REEs. Although $\mathrm{EC}_{50}$ differences appeared between independent studies with A. fischeri (e.g. EC 50 for $\mathrm{Gd}$ can be $6.4 \mathrm{mg} \mathrm{L}-1$ as reported in Gonzales et al. 2015 or $3.53 \mathrm{mg} \mathrm{L}-1$ in Kurvet et al. 2017), they may reflect different experimental setups. However, we report here an $\mathrm{EC}_{50}$ of about $20 \mu \mathrm{M}$ for $\mathrm{Gd}$, which strikingly corresponds to 
that retrieved in Kurvet et al. (2017) for A. fischeri (since the $3.53 \mathrm{mg} \mathrm{L}-1$ used in their study correspond to 22.4 $\mu \mathrm{M})$.

a
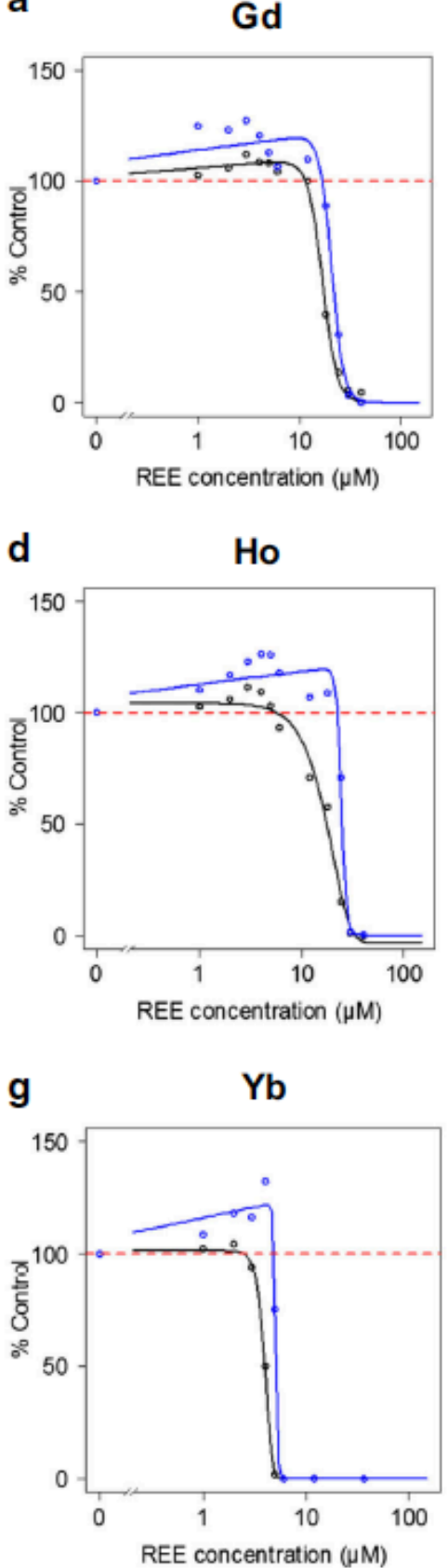

b

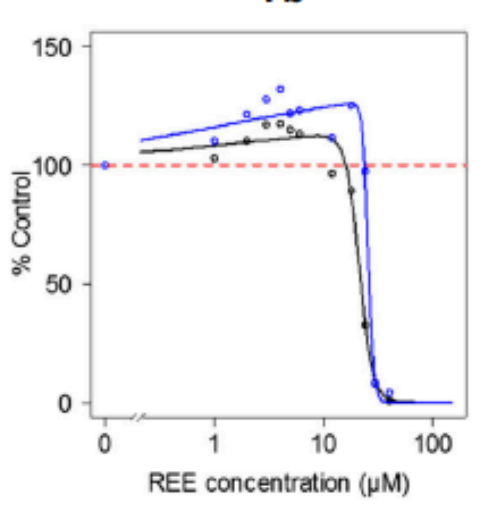

e

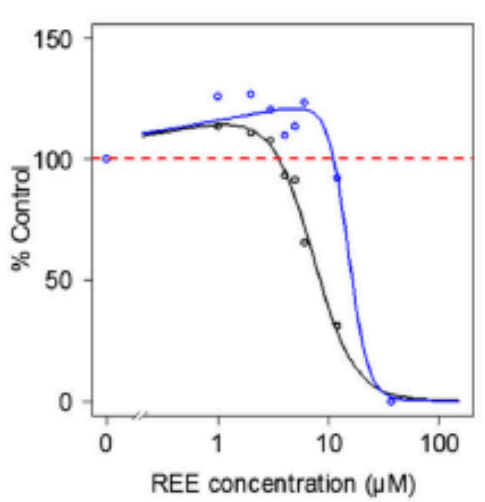

h

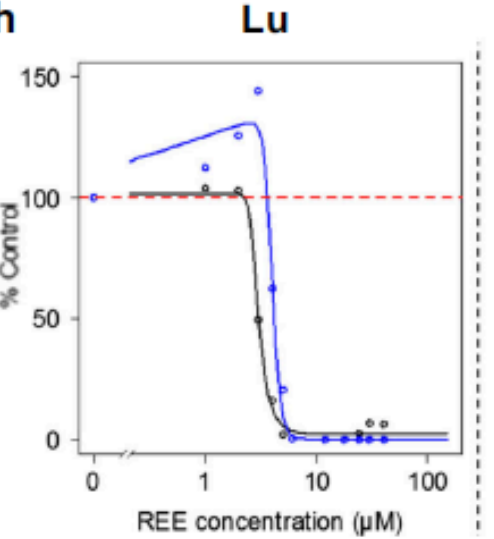

C

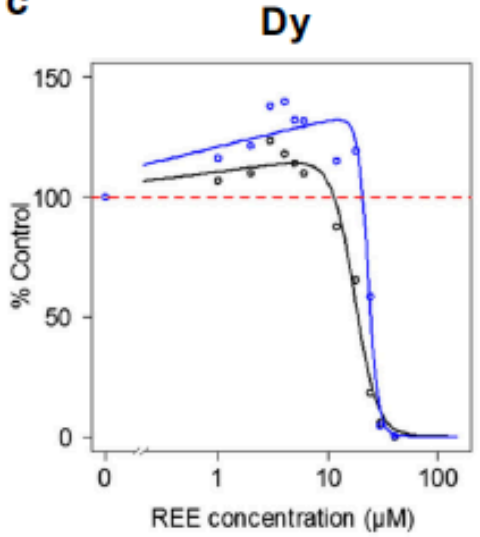

f

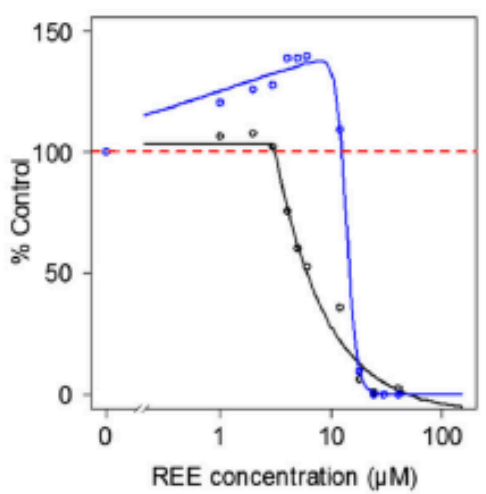

i

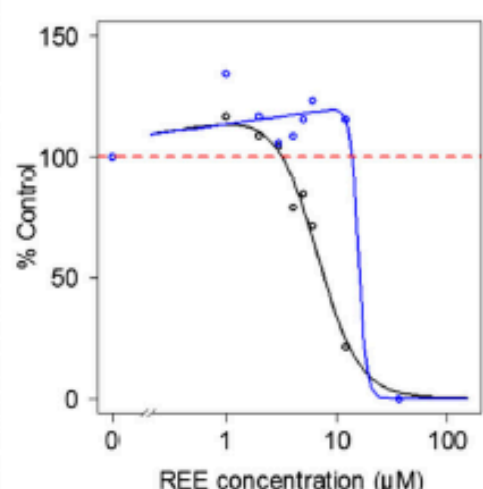

Figure 3. Dose-response curves following $E$. coli exposure to HREEs at mid-log phase (black line) and stationary phase (blue line). Data are expressed as the percentage of the control group (based on $\mathrm{OD}_{600}$ measurements), with the dashed red line representing $100 \%$ of the control.

This finding supports the fact that E. coli can be used to test REE effects in the same way as the other Gramnegative A. fischeri, since the $\mathrm{EC}_{50}$ derived from both studies are in a very close range. Furthermore, several studies have shown an enrichment of HREEs, especially those from $\mathrm{Er}$ to $\mathrm{Lu}$, on the cell surface of either Grampositive or Gram-negative bacteria, including Escherichia coli (Bonificio and Clarke 2016; Takahashi et al. 2005; Takahashi et al. 2010). Such selective enrichments would result from the formation of more stable complexes between HREEs (compared with LREEs) with carboxylate and even more with phosphate binding sites on the bacterial cell surface (Takahashi et al. 2010). Indeed, the bond length between HREEs (Er to Lu) and oxygen from surface binding sites was determined to be shorter than that measured with LREEs (Takahashi et al. 2010). Since REEs can enter bacterial cells and accumulate in the periplasmic space (Bayer and Bayer 1991), selective HREE enrichment on the cell surface may lead to progressively higher bacterial accumulation, thus leading to more cell 
damage and toxicity. The higher toxicity recorded for Sc (LREE) (and to a lesser extent for Y (HREE)) may also be related to the shorter bond length with oxygenrelated cell binding sites (due to the particular REE electronic configuration; Table 1 (Beaudry and Gschneidner 1978)) and subsequent bioavailability.

\begin{tabular}{|c|c|c|c|c|c|c|c|c|c|}
\hline \multirow{2}{*}{\multicolumn{2}{|c|}{ Rare earth element }} & \multirow[b]{2}{*}{$\mathbf{Z}^{\text {a }}$} & \multirow{2}{*}{$\begin{array}{c}\text { Electronic } \\
\text { configuration a }\end{array}$} & \multicolumn{3}{|c|}{ Middle exponential phase } & \multicolumn{3}{|c|}{ Stationary Phase } \\
\hline & & & & $\begin{array}{c}\text { Best } \\
\text { model }\end{array}$ & $\begin{array}{c}\mathbf{E C}_{50} \mathrm{~A} \\
(\mu \mathrm{M})\end{array}$ & $\begin{array}{c}\text { EC }_{50 \_A} \\
\text { (mg.L-1) }\end{array}$ & $\begin{array}{c}\text { Best } \\
\text { model }\end{array}$ & $\begin{array}{c}\mathbf{E C}_{50_{-} \mathrm{B}} \\
(\mu \mathbf{M})\end{array}$ & $\begin{array}{c}\mathbf{E C}_{50 \_B} \\
\left(\mathrm{mg} \cdot \mathrm{L}^{-1}\right)\end{array}$ \\
\hline \multirow{2}{*}{ Lanthanum } & $\mathrm{La} *$ & 57 & $4 f^{0}(5 d 6 s)^{3}$ & CRS.4c & 18.1 & 2.51 & CRS.4c & 22.9 & 3.18 \\
\hline & $\mathrm{La} * *$ & 57 & $4 f^{0}(5 d 6 s)^{3}$ & CRS.4c & 24.6 & 3.42 & CRS.4c & 31.01 & 4.31 \\
\hline Cerium & $\mathrm{Ce}$ & 58 & $4 f^{1}(5 d 6 s)^{3}$ & CRS.4c & 19.7 & 2.76 & CRS.4c & 24.4 & 3.42 \\
\hline Praseodymium & $\operatorname{Pr}$ & 59 & $4 f^{2}(5 d 6 s)^{3}$ & LL.4 & 27.4 & 3.86 & CRS.4c & 44.6 & 6.28 \\
\hline Neodymium & $\mathrm{Nd}$ & 60 & $4 f^{3}(5 d 6 s)^{3}$ & CRS.4c & 19.4 & 2.80 & LL.3 & 24.7 & 3.59 \\
\hline Samarium & $\mathrm{Sm}$ & 62 & $4 f^{5}(5 d 6 s)^{3}$ & LL.5 & 17.2 & 2.59 & LL.4 & 25.8 & 3.88 \\
\hline Europium & $\mathrm{Eu}$ & 63 & $4 f^{7}(5 d 6 s)^{3}$ & CRS.4c & 20.5 & 3.12 & LL. 3 & 27.6 & 4.19 \\
\hline Gadolinium & $\mathrm{Gd}$ & 64 & $4 f^{7}(5 d 6 s)^{3}$ & CRS.4c & 17.2 & 2.70 & CRS.4c & 21.4 & 3.37 \\
\hline Terbium & $\mathrm{Tb}$ & 65 & $4 f^{8}(5 d 6 s)^{3}$ & CRS.4c & 21.9 & 3.48 & CRS.4c & 26.3 & 4.18 \\
\hline Dysprosium & Dy & 66 & $4 f^{9}(5 d 6 s)^{3}$ & CRS.4c & 18.6 & 3.02 & CRS.4c & 24.4 & 3.97 \\
\hline Holmium & Ho & 67 & $4 f^{10}(5 d 6 s)^{3}$ & LL. 5 & 17.4 & 2.87 & CRS.4c & 24.9 & 4.11 \\
\hline Erbium & Er & 68 & $4 f^{11}(5 d 6 s)^{3}$ & CRS.4c & 8.3 & 1.39 & CRS.4c & 16.1 & 2.69 \\
\hline Thullium & $\mathrm{Tm}$ & 69 & $4 f^{12}(5 d 6 s)^{3}$ & LL. 5 & 6.3 & 1.06 & CRS.4c & 14.6 & 2.47 \\
\hline Ytterbium & $\mathrm{Yb}$ & 70 & $4 f^{14}(5 d 6 s)^{3}$ & LL. 5 & 3.98 & 0.69 & CRS.4c & 5.1 & 0.88 \\
\hline Luthetium & $\mathrm{Lu}$ & 71 & $4 f^{14}(5 d 6 s)^{3}$ & LL.5 & 3 & 0.52 & CRS.4c & 4.2 & 0.73 \\
\hline Yttrium & $\mathrm{Y}$ & 39 & $(4 d 5 s)^{3}$ & CRS.4c & 7.6 & 0.68 & CRS.4c & 16.01 & 1.42 \\
\hline Scandium & $\mathrm{Sc}$ & 21 & $(3 d 4 s)^{3}$ & CRS.4c & 1.1 & 0.05 & CRS.4c & 1.5 & 0.07 \\
\hline
\end{tabular}

Table 2. Determination of the best model choice for $\boldsymbol{E}$. coli growth curve modeling and corresponding $\mathrm{EC}_{50}$ estimation following exposure to the 16 studied rare earth elements, at middle exponential phase $\left(\mathrm{EC}_{50_{-} \mathrm{A}}\right)$ and late stationary phase $\left(\mathrm{EC}_{50_{B} \mathrm{~B}}\right)$ of bacterial incubation respectively. ${ }^{\text {a: }}$ electronic properties from Beaudry \& Gnschneider 1978; *: $\mathrm{LaCl}_{3}$; **: $\mathrm{La}_{2}\left(\mathrm{SO}_{4}\right)_{3}$

This would, however, deserve further investigation using high sensitivity spectroscopy, for instance, possibly coupled with imaging techniques. Moreover, it is worth noting that exposure to $\mathrm{LaCl}_{3}$ (EC50_A of $18.1 \mu \mathrm{M}$; Table 1) resulted in slightly higher growth inhibition than $\mathrm{La}_{2}\left(\mathrm{SO}_{4}\right)_{3}\left(\mathrm{EC}_{50} \mathrm{~A}\right.$ of $24.6 \mu \mathrm{M}$; Table 1$)$, suggesting a role for the counter ion in the modulation of REE bioavailability and/or toxicity. Indeed, the presence of anions such as sulfate in a fungi (Rhizopus arrhizus) culture medium was previously reported to inhibit La3+ uptake by the microorganism (Tobin et al. 1987). Similar physicochemical interactions may occur in E. coli culture medium, thus explaining the lower observed toxicity for $\mathrm{La}_{2}\left(\mathrm{SO}_{4}\right)_{3}$ compared with $\mathrm{LaCl}_{3}$ (Table 1, Fig. 1a and Fig. S1A). To better understand the possible time-dependent biological effects of REEs, the assessment of bacterial growth was completed until the control groups reached the late stationary phase (Fig. 1a, c, and e and Figs. S1 and S2). Overall, in the early bacterial growth phase (up to approximately $5 \mathrm{~h}$ of incubation), no strong differences could be reported between the control and low concentration exposure groups (i.e. from 1 to approximately 6 $\mu$ Mdepending on the tested REEs) regarding the growth curve patterns (Fig. 1a, c, and e and Figs. S1 and S2). For the heaviest HREEs (Er to $\mathrm{Lu}$ in addition to Y), exposure at the concentrations around the EC50_A (from 3 to 8.3 $\mu \mathrm{M}$; Table 2) even indicated clear inhibitory effects on microbial growth from the beginning of exposure until entering the stationary phase (Fig. 1 and Figs. S1 and S2). Thus, better bacterial growth was systematically reported when E. coli cultures (including those from Er to Lu) were exposed to the lowest REE concentrations (generally from 1 to $12 \mu \mathrm{M}$ depending on the test compound) (Fig. 1 and Figs. S1, S2, S3, and S4). The same patterns were recorded for the heavier HREEs, with $\mathrm{Yb}$ exposure at $4 \mu \mathrm{M}$ for instance (very close to the EC50_A determined at the middle exponential phase, Table 2), which even led to a significantly higher OD600 compared with the control group at the end of experiments (Fig. 1e). Accordingly, the best model choice for describing dose-response E. coli growth inhibition under REE exposure was generally the hormetic one of Cedergreen-Ritz-Streibig (Table 2). This 
was also related to higher calculated $\mathrm{EC}_{50} \mathrm{~B}$ values for all REEs at late stationary phase, highlighting the importance of the incubation period for the assessment of REE biological effects. Hence, these results revealed a timedependent hormetic effect of REEs considering the bacterial biomass. Several researchers reported similar microbial growth in the presence of heavy metal doped nanoparticles and antibiotics (Migliore et al. 2013; Schacht et al. 2013; Theophel et al. 2014; Wang et al. 2017) or ionic liquids (Nancharaiah and Francis 2015) as chemical stressors, which eventually resulted in higher cellular growth and related stimulatory effects in the late growth or stationary phase. It has been argued that such hormetic observations may indicate an adaptive response to overcorrect the disruption of homeostasis (Calabrese 2015). Accordingly, the delayed E. coli growth observed in the present work may also result in an adaptive response to REE toxicity. Furthermore, since the free ion concentration of REE has been shown to be the main toxic form of these minerals (Weltje et al. 2004), one may also hypothesise that progressive REE sorption onto the bacterial cell surface (with subsequent REE internalization, precipitation, or immobilization) may occur during bacterial incubation. Such phenomena would result in lower REE bioavailability and toxicity for the (even small) bacterial population (from the initial bacterial inoculums), which was not yet concerned with direct elevated REE exposure. The remaining fraction of bioavailable REEs in the exposure medium may then be involved in the observed hormetic bacterial growth. Indeed, recent studies demonstrated functional roles of lanthanides such as $\mathrm{La}, \mathrm{Ce}, \mathrm{Nd}, \mathrm{Pr}$, and $\mathrm{Sm}$ in the regulation of the enzyme activity of a number of alcohol dehydrogenases in Gram-negative bacteria, optimizing cell growth in the presence of REEs (in the $\mathrm{nM}$ to a few $\mu \mathrm{M}$ range) (Vu et al. 2016; Wehrmann et al. 2017). In our work, similar upregulation of catabolism activity may occur with E. coli, which would lead to a better substrate use efficiency of the minimal growth medium and ultimately to higher bacterial growth at the lowest concentrations of REEs during the exposure period.

\section{REE toxicity assessment at the physiological level}

As shown in Fig. 4a, the mean percentage of BODIPY-C4- labelled cells was significantly higher in all REEexposed cells compared with the control group. Moreover, the fraction of labelled cells was also more marked in Gd- and Yb-exposed bacteria compared with La-exposed bacteria (Fig. 4a).

A)

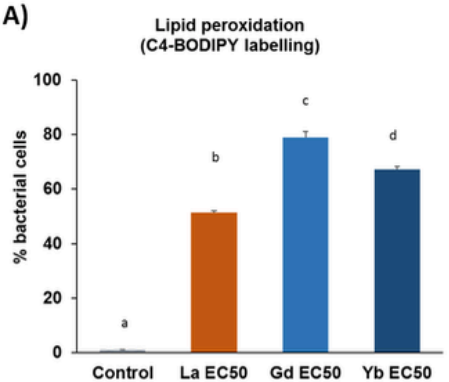

C)

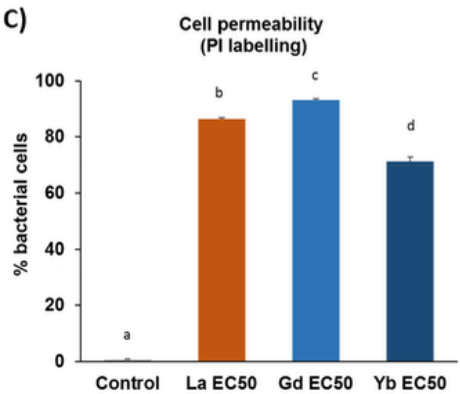

B)
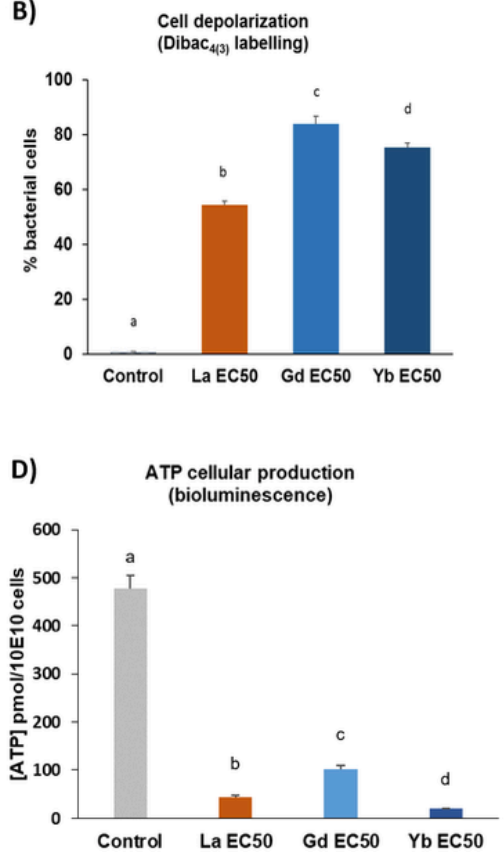

Figure 3. Subcellular parameters determined by flow cytometry (A, B and C) and bioluminescence (D) after $E$. coli exposure to the corresponding EC50 A of $\mathrm{LaCl}$, GdCl3 and $\mathrm{YbCl}$ (determined the midlog phase). (A)(B)(C) Data are expressed as the percentage (mean $+/-\mathrm{SD} ; \mathrm{n}=3$ ) of labelled cells relative to the total cell count. Total bacterial cells were determined in each sample by using Syto9 labelling. (D) Cellular ATP production is expressed as the mean $(+/-\mathrm{SD} ; \mathrm{n}=3)$ of ATP concentration relative to $10^{\mathrm{e}} 10$ cells. Letters indicate significant differences between groups $(p<0.05)$.

Taken together, these results indicated that REE toxicity mechanisms are involved in lipid membrane peroxidation processes, which were more evident in the presence of HREEs (Gd and Yb) compared with LREEs (with La as a representative). The same patterns could be observed when monitoring the bacterial cell membrane depolarization (through DiBAC4(3) labelling, Fig. 4b). Indeed, REE treatment with the corresponding EC50_A resulted in a higher 
membrane depolarization for $\mathrm{Gd}$ and $\mathrm{Yb}$ than for $\mathrm{La}$, with the stronger value being observed for $\mathrm{Gd}(84 \%)$ (Fig. $4 \mathrm{~b})$. Similarly, these bacterial membrane damages were associated with significantly higher proportions of PIstained cells following REE exposure, in the range of 86, 93, and 71\% for La-, Gd- and Yb-treated cells, respectively (Fig. 4c). Thus, substantial disturbance of E. coli membrane integrity occurred therefore confirming the previously reported damage to membrane structure (Fig. 4a, b), which is usually related to lower cell viability (Sohm et al. 2015). Moreover, ATP cellular production decreased more than 5 times for these 3 REEs at their $\mathrm{EC}_{50} \mathrm{~A}$ (Fig. 4d). This reduction in ATP production is consistent with the cell membrane depolarization observed since ATP synthesis requires the membrane potential (Dimroth et al. 2000). These results illustrated the toxicity potential of REEs at elevated exposure levels (in the range of ECs0 total concentration). However, the REE adsorption potential at the bacterial cell surface, thus locally increasing the REE concentration (Bonificio and Clarke 2016; Takahashi et al. 2005), may lead to antibacterial effects even at environmental concentrations lower than the reported $\mathrm{EC}_{50}$. With this in mind, flow cytometry techniques combined with the use of adequate fluorescent probes may also help in developing in situ monitoring of cellular biomarkers to better address the long-term ecotoxicity potential of REEs regarding bacterial populations (Besmer et al. 2014).

\section{Conclusion}

Previous toxicity studies have addressed the REE effects on the marine bacterium A. fischeri, mainly through standard toxicity testing procedures based on bioluminescence inhibition assays. To our knowledge, no simultaneous characterization of the 16 REE toxicity effects has been made on the kinetic growth of the model Gram-negative bacterium E. coli using minimal medium. This was therefore the primary aim of this paper. Bacterial growth monitoring under laboratory conditions showed that the 16 studied REEs could be toxic to microbial cells in a concentration-dependent manner and follow a global pattern of HREEs being more toxic than LREEs. There was however an exception with scandium, which is considered a "LREE" but is by far the most toxic compound with an $\mathrm{EC}_{50}$ of $1.1 \mu \mathrm{M}(0.05 \mathrm{mg} \mathrm{L}-1)$. Moreover, in our study, time-dependent hormetic effects could be systematically reported regarding bacterial biomass at the lowest tested REE exposure concentrations, suggesting adaptive mechanisms during REE exposure. Assessment of bacterial injury confirmed the toxicity potential of rare earth elements through cell membrane damage involving lipid peroxidation along with enhanced membrane permeability and depolarization, which consequently impaired ATP production. In perspective, further intracellular REE concentration determination combined with cellular imaging and molecular analyses (e.g. transcriptomic techniques) may pave the way to a better understanding of the hormetic and toxicity processes associated with REE exposure.

\section{Acknowledgements}

The authors would like to thank Christophe Pagnout for the generous gift of the fluorescent probes and his valuable advice in flow cytometry analysis and ATP measurements. The GISFI (Groupement d'Intérêt Scientifique sur les Friches Industrielles) is also acknowledged. Funding information This work was supported by the French National Research Agency through the National Program "Investissements d'Avenir" with the reference ANR-10-LABX21-01/LABEX RESSOURCES21 and by the Région Grand-Est.

\section{Compliance with ethical standards}

The authors declare that there is no conflict of interest.

\section{References}

Agathokleous E, KitaoM, Calabrese EJ (2018) Hormetic dose responses induced by lanthanum in plants. Environ Pollut 244:332-341 BayerME, BayerMH(1991) Lanthanide accumulation in the periplasmic space of Escherichia coli B. J Bacteriol 173:141-149

Beaudry BJ, Gschneidner KA (1978): Chapter 2 Preparation and basic properties of the rare earth metals, Handbook on the physics and chemistry of rare earths. Elsevier, pp 173-232

Bellin M-F, Van Der Molen AJ (2008) Extracellular gadolinium-based contrast media: an overview. Eur J Radiol 66:160-167 Besmer MD, Weissbrodt DG, Kratochvil BE, Sigrist JA, Weyland MS, Hammes F (2014) The feasibility of automated online flow cytometry for in-situ monitoring of microbial dynamics in aquatic ecosystems. Front Microbiol:5

Biebl H, Pfennig N (1981) Isolation of members of the family Rhodospirillaceae. In: Starr MP, Stolp H, Trüper HG, Balows A, Schlegel HG (eds) The prokaryotes: a handbook on habitats, isolation, and identification of Bacteria. Springer Berlin Heidelberg, Berlin, Heidelberg, pp 267-273

Blount ZD (2015) The unexhausted potential of E. coli. Elife 4:e05826 Bonificio WD, Clarke DR (2016) Rare-earth separation using bacteria. Environ Sci Technol Lett 3:180-184

Borremans B, Hobman JL, Provoost A, Brown NL, van der Lelie D (2001) Cloning and functional analysis of the pbr lead resistance determinant of Ralstonia metallidurans CH34. J Bacteriol 183: 5651-5658

Cai L, Park YS, Seong SI, Yoo SW, Kim IH (2015) Effects of rare earth elements-enriched yeast on growth performance, nutrient digestibility, meat quality, relative organ weight, and excreta microflora in broiler chickens. Livest Sci 172:43-49

Calabrese EJ (2015) Hormesis within a mechanistic context. Homeopathy 104:90-96

Connely NG, Damhus T, Harstshorn RM, Hutton AT (2005) Nomenclature of inorganic chemistry IUPAC recommendations 2005. ISBN 10: 0854044388. Royal Society of Chemistry, United Kingdom 
Cotton S, Harrowfield J (2012) Lanthanides: biological activity and medical applications, Encyclopedia of Inorganic and Bioinorganic Chemistry

Dimroth P, Kaim G, Matthey U (2000) Crucial role of the membrane potential for atp synthesis by f1 fo Atp synthases. J Exp Biol 203 : $51-59$

Ghahramani MR, Garibov AA, Agayev TN (2013) Production and quality control of radioactive yttrium microspheres for medical applications. Appl Radiat Isot 85:87-91

González V, Vignati DAL, Leyval C, Giamberini L (2014) Environmental fate and ecotoxicity of lanthanides: are they a uniform group beyond chemistry? Environ Int 71:148-157

González V, Vignati DAL, Pons M-N, Montarges-Pelletier E, Bojic C, Giamberini L (2015) Lanthanide ecotoxicity: first attempt to measure environmental risk for aquatic organisms. Environ Pollut 199: 139-147

Haque N, Hughes A, Lim S, Vernon C (2014) Rare earth elements: overview of mining, mineralogy, uses, sustainability and environmental impact. Resources 3:614

Hissler C, Stille P, Guignard C, Iffly JF, Pfister L (2014) Rare earth elements as hydrological tracers of anthropogenic and critical zone contributions: a case study at the Alzette River basin scale. Procedia Earth and Planetary Science 10:349-352

Jackson RJ, Binet MRB, Lee LJ,Ma R, Graham AI, McLeod CW, Poole RK (2008) Expression of the PitA phosphate/metal transporter of Escherichia coli is responsive to zinc and inorganic phosphate levels. FEMS Microbiol Lett 289:219-224

Jang J, Hur H-G, Sadowsky MJ, Byappanahalli MN, Yan T, Ishii S (2017) Environmental Escherichia coli: ecology and public health implications - a review. J Appl Microbiol 123:570-581

Kraatz M, Taras D,MännerK, Simon O(2006)Weaning pig performance and faecal microbiota with and without in-feed addition of rare earth elements. J Anim Physiol Anim Nutr 90:361-368

Kurvet I, Juganson K, Vija H, Sihtmäe M, Blinova I, Syvertsen-Wiig G, Kahru A (2017) Toxicity of nine (doped) rare earth metal oxides and respective individual metals to aquatic microorganisms Vibrio fischeri and Tetrahymena thermophila. Materials (Basel, Switzerland) 10:754

Lemke MJ, Churchill PF, Wetzel RG (1995) Effects of substrate and cell surface hydrophobicity on phosphate utilization in bacteria. App Env Micro 61(3):913-919

Mergeay M, Nies D, Schlegel HG, Gerits J, Charles P, Van Gijsegem F (1985) Alcaligenes eutrophusCH34 is a facultative chemolithotroph with plasmid-bound resistance to heavy metals. J Bacteriol 162: 328-334

Migaszewski ZM, Gałuszka A (2015) The characteristics, occurrence, and geochemical behavior of rare earth elements in the environment: a review. Crit Rev Environ Sci Technol 45:429-471

Migliore L, Rotini A, Thaller MC (2013) Low doses of tetracycline trigger the E. coli growth: a case of hormetic response. Doseresponse 11, dose-response.13-002.Migliore

Nancharaiah YV, Francis AJ (2015) Hormetic effect of ionic liquid 1- ethyl-3-methylimidazolium acetate on bacteria. Chemosphere 128: $178-183$

Neidhardt FC, Bloch PL, Smith DF (1974) Culture medium for Enterobacteria. J Bacteriol 119:736-747

Nuss P, Blengini GA (2018) Towards better monitoring of technology critical elements in Europe: coupling of natural and anthropogenic cycles. Sci Total Environ 613-614:569-578

Outten FW, Huffman DL, Hale JA, O'Halloran TV (2001) The independent cue and cusSystems confer copper tolerance during aerobic and anaerobic growth in Escherichia coli. J Biol Chem 276:30670-30677

Pang X, Li D, Peng A (2001) Application of rare-earth elements in the agriculture of China and its environmental behavior in soil. J Soils Sediments 1:124

R Core Team (2013) R: a language and environment for statistical computing. R Foundation for Statistical Computing, Vienna, Austria. http://www.R-project.org

Ritz C, Streibig JC (2005): Bioassay analysis using R. 2005 12, 22

Sachs S, Heller A, Weiss S, Bok F, Bernhard G (2015) Interaction of Eu(III) with mammalian cells: cytotoxicity, uptake, and speciation as a function of $\mathrm{Eu}(\mathrm{III})$ concentration and nutrient composition. Toxicol in Vitro 29:1555-1568

Schacht VJ, Neumann LV, Sandhi SK, Chen L, Henning T, Klar PJ, Theophel K, Schnell S, Bunge M (2013) Effects of silver nanoparticles on microbial growth dynamics. J Appl Microbiol 114:25-35

Sohm B, Immel F, Bauda P, Pagnout C (2015) Insight into the primary mode of action of TiO2 nanoparticles on Escherichia coli in the dark. PROTEOMICS 15:98-113

Takahashi Y, Châtellier X, Hattori KH, Kato K, Fortin D (2005) Adsorption of rare earth elements onto bacterial cell walls and its implication for REE sorption onto natural microbial mats. Chem Geol 219:53-67

Takahashi Y, Yamamoto M, Yamamoto Y, Tanaka K (2010) EXAFS study on the cause of enrichment of heavy REEs on bacterial cell surfaces. Geochim Cosmochim Acta 74:5443-5462

Theophel K, Schacht VJ, Schlüter M, Schnell S, Stingu C-S, Schaumann R, Bunge M (2014) The importance of growth kinetic analysis in determining bacterial susceptibility against antibiotics and silver nanoparticles. Front Microbiol 5:544-544

Tobin JM, Cooper DG, Neufeld RJ (1987) Influence of anions on metal adsorption by Rhizopus arrhizus biomass. Biotechnol Bioeng 30: $882-886$

Uchida S, Tagami K, Tabei K, Hirai I (2006) Concentrations of REEs, Th and U in river waters collected in Japan. J Alloys Compd 408-412: 525-528

Vu HN, Subuyuj GA, Vijayakumar S, Good NM, Martinez-Gomez NC, Skovran E (2016) Lanthanide-dependent regulation of methanol oxidation systems in Methylobacterium extorquens AM1 and their contribution to methanol growth. J Bacteriol 198:12501259

Wakabayashi T, Ymamoto A, Kazaana A, Nakano Y, Nojiri Y, Kashiwazaki M (2016) Antibacterial, antifungal and nematicidal activities of rare earth ions. Biol Trace Elem Res 174:464-470

Walk ST, Alm EW, Gordon DM, Ram JL, Toranzos GA, Tiedje JM, Whittam TS (2009) Cryptic lineages of the genus Escherichia. Appl Environ Microbiol 75:6534-6544

Wang D, Lin Z,Wang T,DingX, LiuY(2017) An analogous wood barrel theory to explain the occurrence of hormesis: a case study of sulfonamides and erythromycin on Escherichia coli growth. PLoS One 12: e0181321

WehrmannM, Billard P, Martin-Meriadec A, Zegeye A, Klebensberger J (2017) Functional role of lanthanides in enzymatic activity and transcriptional regulation of pyrroloquinoline quinone-dependent alcohol dehydrogenases in Pseudomonas putida KT2440. mBio 8: e00570-17 
Weltje L, Verhoof LRCW, Verweij W, Hamers T (2004) Lutetium speciation and toxicity in a microbial bioassay: testing the free-ion model for lanthanides. Environ Sci Technol 38:6597-6604

Wenhua L, Ruming Z, Zhixiong X, Xiangdong C, Ping S (2003) Effects of La3+ on growth, transformation, and gene expression of Escherichia coli. Biol Trace Elem Res 94:167-177

A)

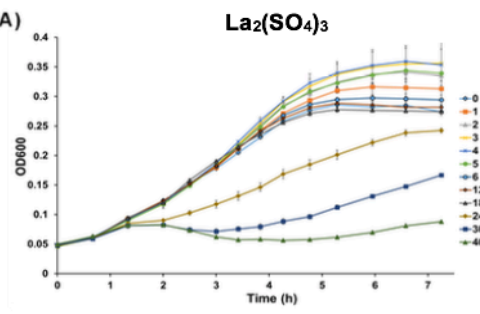

D)

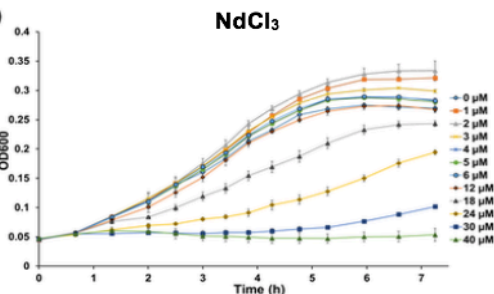

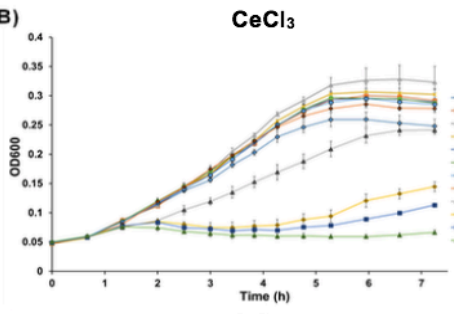

E) $0.4 \quad \mathrm{SmCl}_{3}$

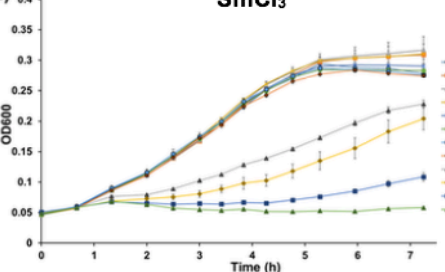

C)

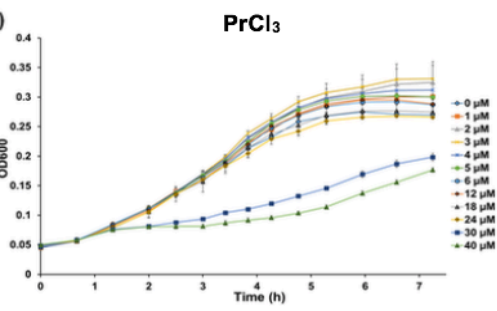

$\mathrm{EuCl}_{3}$

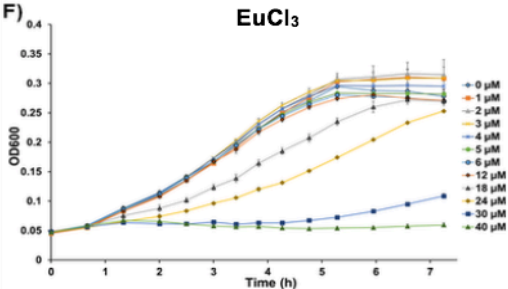

G)

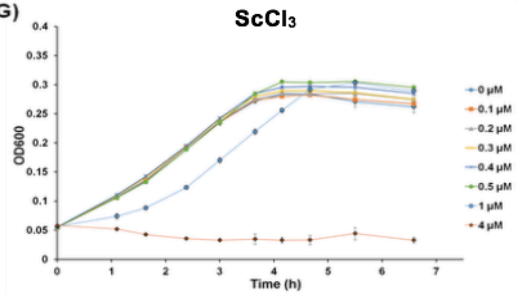

Figure S1. Growth curves of $E$. coli during incubation with $\mathrm{LREEs}$ : $\mathrm{La}_{2}\left(\mathrm{SO}_{4}\right)_{3}, \mathrm{CeCl}_{3}, \mathrm{PrCl}_{3}, \mathrm{NdCl}_{3}, \mathrm{SmCl}_{3}, \mathrm{EuCl}_{3}$ and $\mathrm{ScCl}_{3}$. Data are expressed as the mean $+/-\mathrm{SD}(\mathrm{n}=3)$.
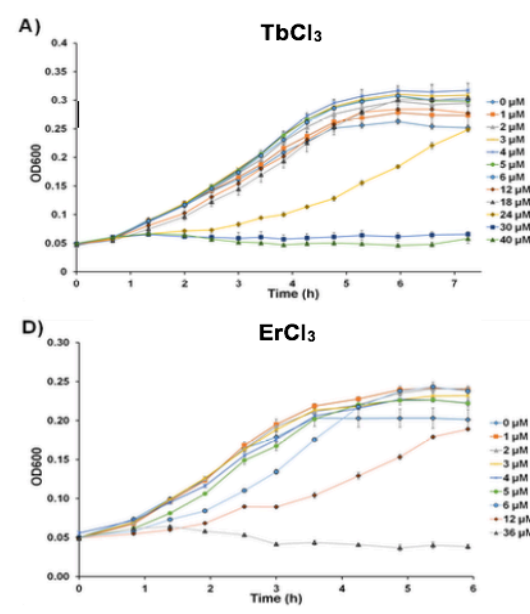

G)

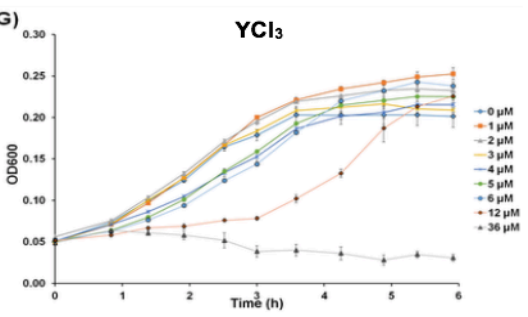

B)

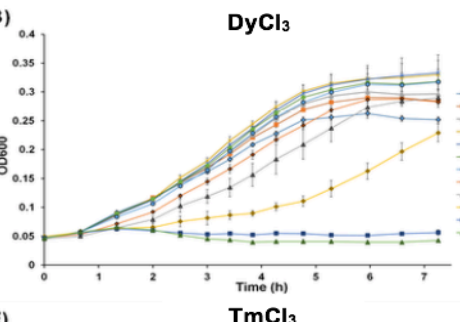

E)

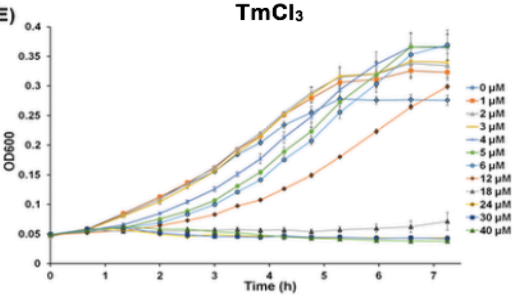

C) $\mathrm{HoCl}_{3}$
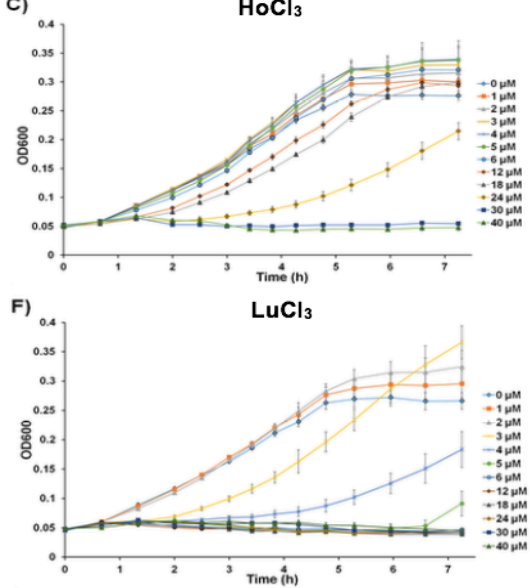

Figure S2. Growth curves of $E$. coli during incubation with $\mathrm{HREEs}$ : $\mathrm{TbCl}_{3}, \mathrm{DyCl}_{3}, \mathrm{HoCl}_{3}, \mathrm{ErCl}_{3}, \mathrm{TmCl}_{3}, \mathrm{LuCl}_{3}$ and $\mathrm{YCl}_{3}$. Data are expressed as the mean $+/-\operatorname{SD}(n=3)$. 

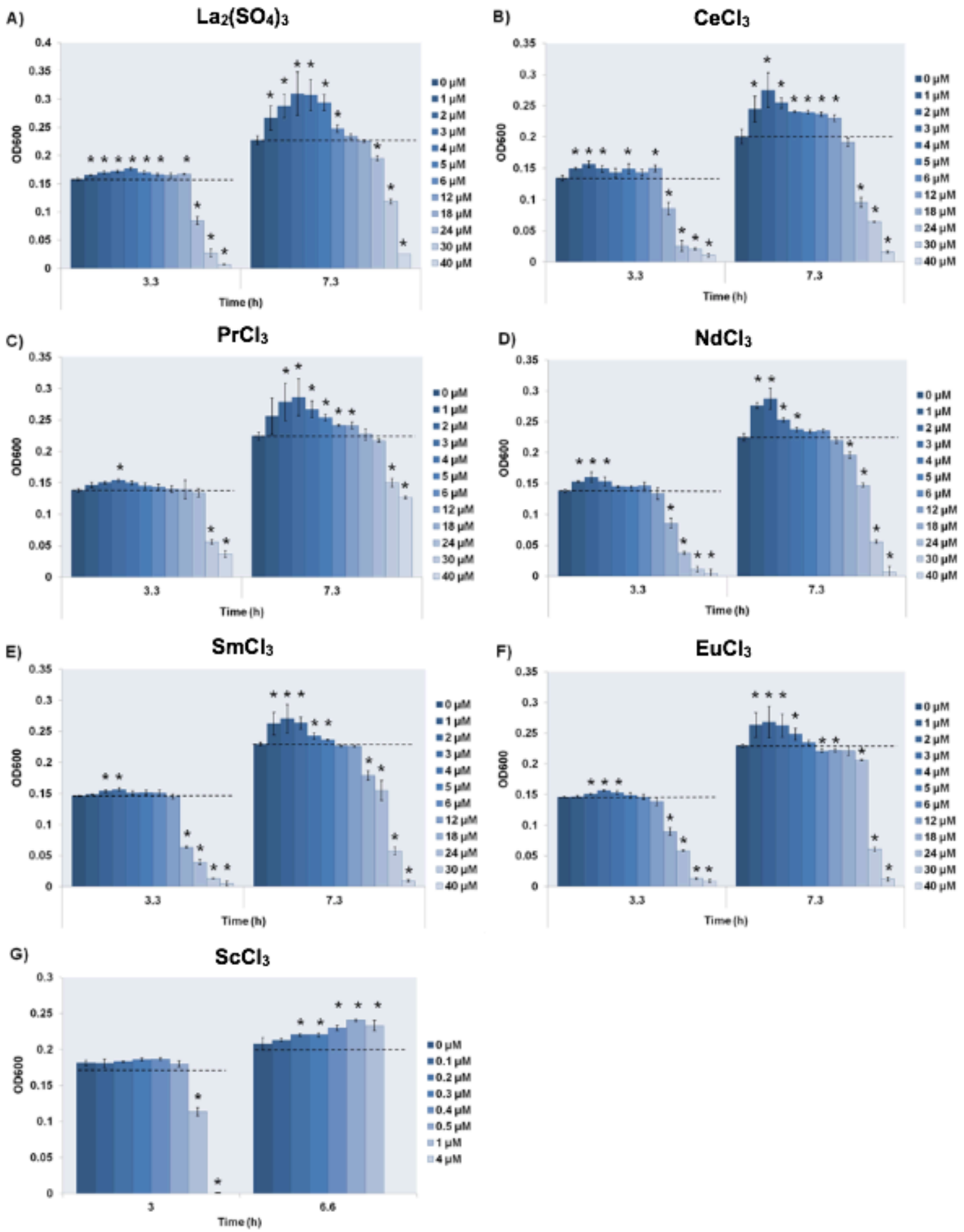

Figure S3. $\mathrm{OD}_{600}$ of $E$. coli cultures (determined in the mid-log and stationary phase) during incubation with LREEs: $\mathrm{La}_{2}\left(\mathrm{SO}_{4}\right)_{3}, \mathrm{CeCl}_{3}, \mathrm{PrCl}_{3}, \mathrm{NdCl}_{3}, \mathrm{SmCl}_{3}, \mathrm{EuCl}_{3}$ and $\mathrm{ScCl}_{3}$. Data are expressed as the mean $+/-\mathrm{SD}(\mathrm{n}=3) .{ }^{*}$ indicates significant difference from the control group $(p<0.05)$. 
A)

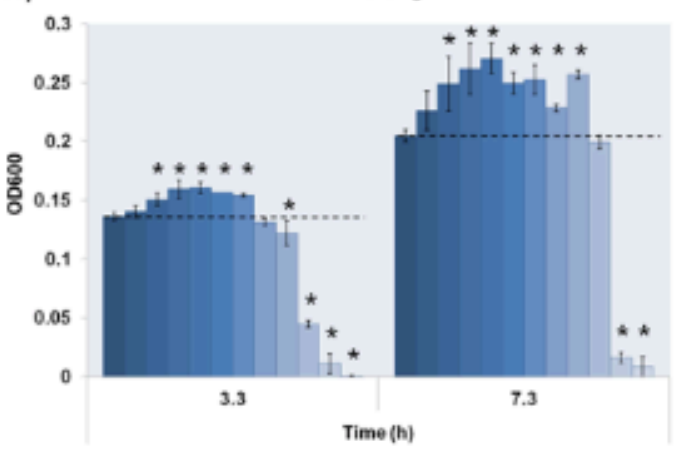

C)

C) 0.35

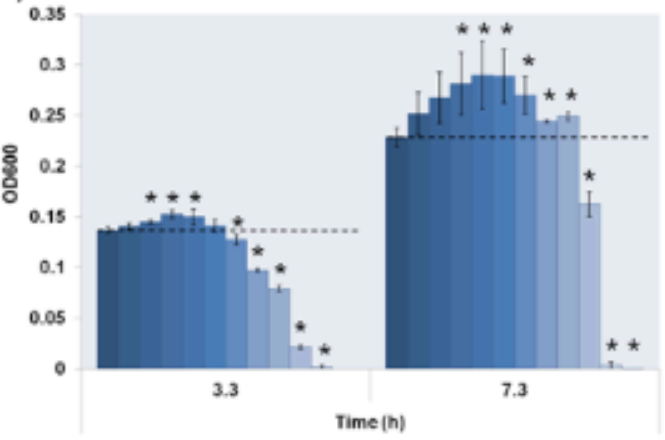

E)

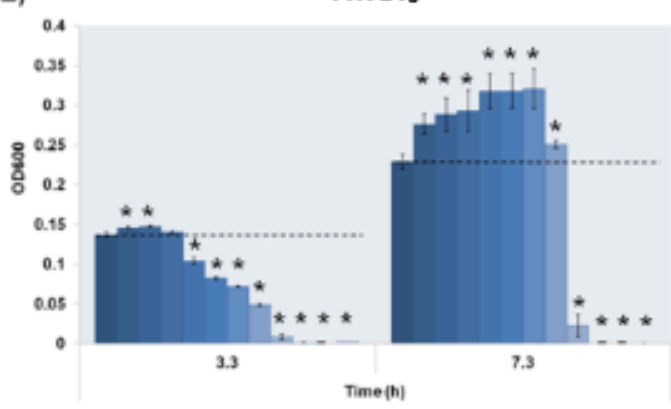

G)

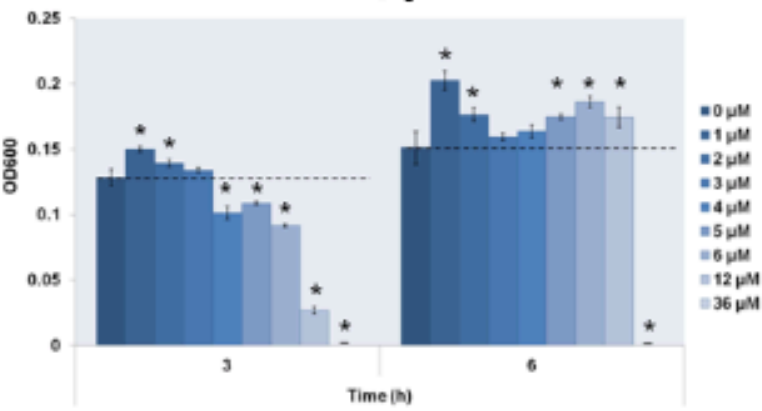

B)
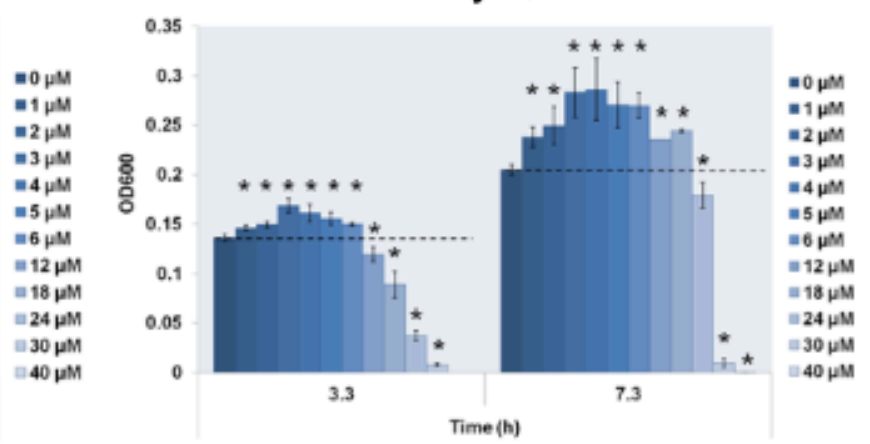

D)

$\mathrm{ErCl}_{3}$

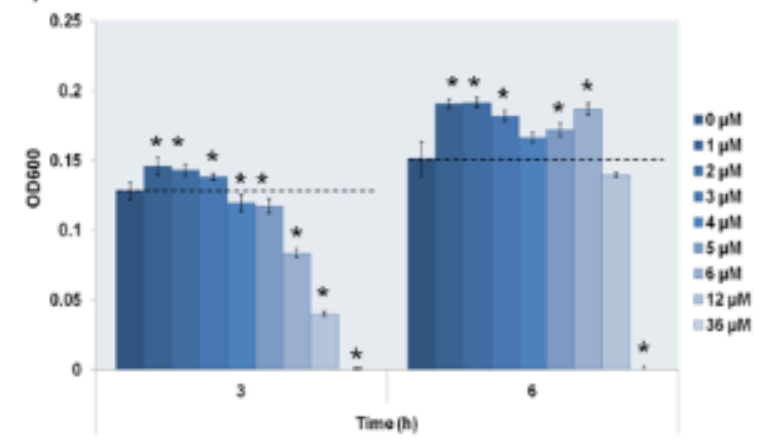

F)

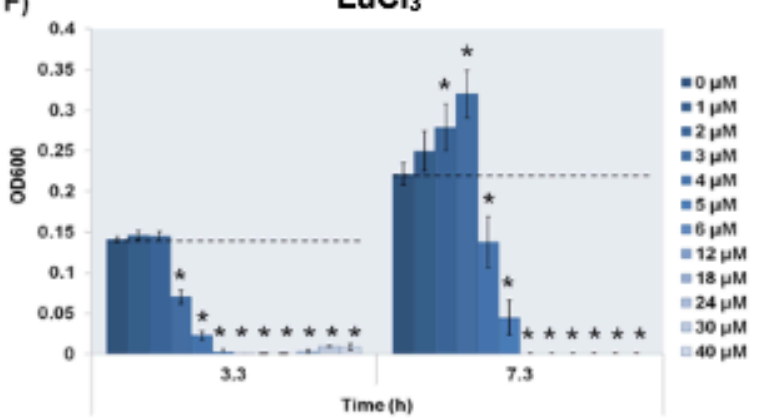

Figure S4. OD 600 of $E$. coli cultures (determined in the mid-log and stationary phase) during incubation with $\mathrm{HREEs}_{\mathrm{TbCl}}, \mathrm{DyCl}_{3}, \mathrm{HoCl}_{3}, \mathrm{ErCl}_{3}, \mathrm{TmCl}_{3}, \mathrm{LuCl}_{3}$ and $\mathrm{YCl}_{3}$. Data are expressed as the mean $+/-\mathrm{SD}(\mathrm{n}=3){ }^{*}$ indicates significant difference from the control group $(p<0.05)$. 